\title{
Geographic Differences in Patients in a Global Acute Heart Failure Clinical Trial (from the ASCEND-HF Trial)
}

\section{Metra, Marco}

2016-06-01

Metra , M , Mentz , R J , Hernandez , A F , Heizer , G M , Armstrong , P W , Clausell , N , Corbalan , R , Costanzo , M R, Dickstein , K, Dunlap , M E , Ezekowitz , J A , Howlett , J G , Komajda , M , Krum , H , Lombardi , C , Fonarow , G C , McMurray , J J V , Nieminen , M S , Swedberg , K, Voors , A A , Starling , R C , Teerlink, J R \& O'Connor , C M 2016 , ' Geographic Differences in Patients in a Global Acute Heart Failure Clinical Trial (from the ASCEND-HF Trial) ' , American Journal of Cardiology , vol. 117 , no. 11, pp. 1771-1778 . https://doi.org/10.1016/j.an

http://hdl.handle.net/10138/224044

https://doi.org/10.1016/j.amjcard.2016.03.002

publishedVersion

Downloaded from Helda, University of Helsinki institutional repository.

This is an electronic reprint of the original article.

This reprint may differ from the original in pagination and typographic detail.

Please cite the original version. 


\title{
Geographic Differences in Patients in a Global Acute Heart Failure Clinical Trial (from the ASCEND-HF Trial)
}

\author{
Marco Metra, MD ${ }^{\mathrm{a}, *}$, Robert J. Mentz, MD ${ }^{\mathrm{b}}$, Adrian F. Hernandez, MD, MHS ${ }^{\mathrm{b}}$, \\ Gretchen M. Heizer, MS ${ }^{\mathrm{b}}$, Paul W. Armstrong, MD ${ }^{\mathrm{c}}$, Nadine Clausell, MD ${ }^{\mathrm{d}}$, Ramon Corbalan, $\mathrm{MD}^{\mathrm{e}}$, \\ Maria Rosa Costanzo, $\mathrm{MD}^{\mathrm{f}}$, Kenneth Dickstein, MD, PhD ${ }^{\mathrm{g}}$, Mark E. Dunlap, $\mathrm{MD}^{\mathrm{h}}$, \\ Justin A. Ezekowitz, MBBCh, MSc ${ }^{c}$, Jonathan G. Howlett, MD ${ }^{i}$, Michel Komajda, MD, \\ Henry Krum, MBBS, PhD ${ }^{\mathrm{k}}$, Carlo Lombardi, MD ${ }^{\mathrm{a}}$, Gregg C. Fonarow, MD ${ }^{1}$, John J.V. McMurray, MD ${ }^{\mathrm{m}}$, \\ Markku S. Nieminen, $\mathrm{MD}^{\mathrm{n}}$, Karl Swedberg, $\mathrm{MD}^{\mathrm{o}}$, Adriaan A. Voors, MD, $\mathrm{PhD}^{\mathrm{p}}$, \\ Randall C. Starling, MD, MPH ${ }^{\mathrm{q}}$, John R. Teerlink, MD ${ }^{\mathrm{r}, \mathrm{s}}$, and Christopher M. O'Connor, MD ${ }^{\mathrm{b}}$
}

A growing number of countries and geographical regions are involved in major clinical trials. Acute Study of Clinical Effectiveness of Nesiritide in Decompensated Heart Failure is the largest trial in acutely decompensated heart failure (HF) with patients from 5 geographical regions: North America (NA), Latin America (LA), Western Europe (WE), Central Europe (CE), and Asia-Pacific (AP). Data from the 5 geographical areas were compared including baseline characteristics, medications, 30-day outcomes (mortality and mortality or HF hospitalization), and 180-day mortality. Of the 7,141 study patients, 3,243 (45.4\%) were from NA (average of 15.2 patients/site), 1,762 (24.7\%) from AP (28.4 patients/ site), 967 (13.5\%) from CE (20.2 patients/site), 665 (9.3\%) from LA (17.1 patients/site), and $504(7.1 \%)$ from WE (14.4 patients/site). There were marked differences in co-morbidities, clinical profile, medication use, length of stay, 30-day event rates, and 180-day mortality by region. Compared with NA, the adjusted risk for death or HF hospitalization at 30 days was significantly lower in CE (odds ratio [OR] 0.46, 95\% CI 0.33 to 0.64 ), WE (OR $0.5295 \%$ CI 0.35 to 0.75 ), and AP (OR $0.6295 \%$ CI 0.48 to 0.79 ) and numerically lower in LA (OR 0.77 , 95\% CI 0.57 to 1.04 ) with similar results for 180-day mortality. In conclusion, in patients with acutely decompensated HF, major differences in baseline characteristics, treatments, length of the hospital stay, and 30-day HF rehospitalization rates, and 180-day mortality were found in patients enrolled from different geographical areas. 다일 2016 Elsevier Inc. All rights reserved. (Am J Cardiol 2016;117:1771-1778)

Cardiovascular clinical research, including research of new therapies for heart failure (HF), is undergoing progressive globalization. ${ }^{1-4}$ This is caused in part by the improvement in chronic HF treatment with a decrease in event rates and the need to detect smaller effects for new drugs (i.e., the requirement for large sample sizes), as well as by financial and recruitment challenges in regions such as North America (NA) and the desire to capitalize on emerging world markets. This shift in trial conduct is

${ }^{\mathrm{a} D i v i s i o n}$ of Cardiology, Department of Medical and Surgical Specialties, University of Brescia, Brescia, Italy; ${ }^{\mathrm{b}}$ Duke Clinical Research Institute, Division of Cardiology, Department of Medicine, Duke University Medical Center, Durham, North Carolina; 'Division of Cardiology, University of Alberta, Edmonton, Alberta, Canada; ${ }^{\mathrm{d} S e r v i c ̧ o ~ d e ~ C a r-~}$ diologia, Hospital de Clinicas de Porto Alegre, Porto Alegre, Brazil; ${ }^{\mathrm{e}}$ Cardiovascular Division, Pontificia Universidad Catolica deChile, Santiago, Chile; ${ }^{\mathrm{f}}$ Advocate Heart Institute, Naperville, Illinois; ${ }^{\mathrm{g}}$ Cardiology Division, Stavenger University Hospital, University of Bergen, Bergen, Norway; ${ }^{\mathrm{h}}$ Heart and Vascular Center, Metrohealth Medical Center, Cleveland, Ohio; i Libin Cardiovascular Institute, University of Calgary, Calgary, Alberta, Canada; ${ }^{\mathrm{j}}$ Pitie Salpetriere Hospital, University Pierre Marie Curie, Paris, France; ${ }^{\mathrm{k}}$ Centre of Cardiovascular Research and Education in Therapeutics, Monash University, Melbourne, Australia; ${ }^{1}$ Ahmanson-UCLA Cardiomyopathy Center, University of California, Los associated with a decreasing number of patients enrolled in NA and Western Europe (WE) and with increasing recruitment from Central Europe (CE), Latin America (LA), and, more recently, the Asia-Pacific (AP) region. Heterogeneity of geographical areas may, however, have a major impact on the results and interpretation of clinical trials. $^{5-10}$ The Acute Study of Clinical Effectiveness of Nesiritide in Decompensated Heart Failure (ASCEND-HF) trial is the largest randomized controlled trial in patients

\footnotetext{
Angeles, Los Angeles, California; ${ }^{\mathrm{m}}$ BHF Cardiovascular Research Centre, University of Glasgow, Glasgow, United Kingdom; ${ }^{\mathrm{n}}$ Heart and Lung Center, Meilahti Hospital, Helsinki, Finland; ${ }^{\circ}$ Department of Emergency and Cardiovascular Medicine, Sahlgrenska Academy, University of Gothenburg, Sweden; ${ }^{\mathrm{p}}$ Department of Cardiology, University Medical Center Groningen, Groningen, the Netherlands; ${ }^{\mathrm{q}}$ Department of Cardiovascular Medicine, Heart and Vascular Institute, Cleveland Clinic, Cleveland, Ohio; ${ }^{\mathrm{r}}$ Division of Cardiology, University of California, San Francisco, San Francisco, California; and 'San Francisco Veterans Affairs Medical Center, San Francisco, California. Manuscript received December 29, 2015; revised manuscript received and accepted March 8, 2016.

See page 1777 for disclosure information.

*Corresponding author: Tel: $(+39)$ 030-3995573; fax: $(+39) 030$ 307221.
}

E-mail address: metramarco@libero.it (M. Metra). 
Table 1

Baseline characteristics of the patients subdivided by geographical areas

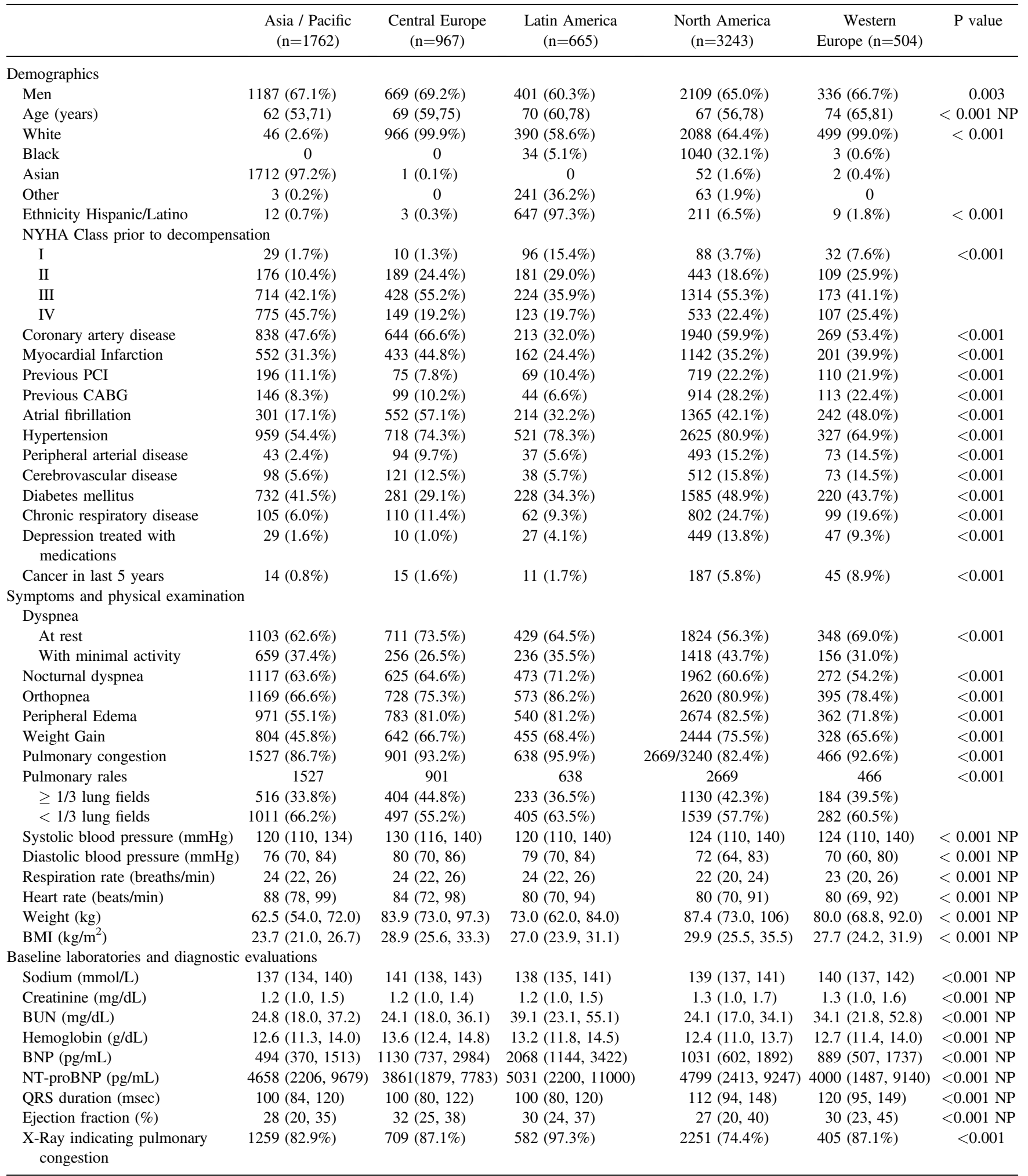

All data are shown as $\mathrm{n}(\%)$ or median $(\mathrm{Q} 1, \mathrm{Q} 3)$ unless otherwise specified.

$\mathrm{BMI}=$ body mass index $; \mathrm{BNP}=$ brain natriuretic peptide; $\mathrm{BUN}=$ blood urea nitrogen $\mathrm{CABG}=$ coronary artery bypass grafting; $\mathrm{NP}=$ nonparametric test; NT-proBNP $=$ N-terminal pro brain natriuretic peptide; NYHA $=$ New York Heart Association; PCI $=$ percutaneous coronary intervention. 
Table 2

Treatments by world region (prerandomization and discharge)

\begin{tabular}{|c|c|c|c|c|c|c|}
\hline & $\begin{array}{c}\text { Asia / Pacific } \\
\quad(n=1762)\end{array}$ & $\begin{array}{l}\text { Central Europe } \\
\quad(n=967)\end{array}$ & $\begin{array}{l}\text { Latin America } \\
\quad(n=665)\end{array}$ & $\begin{array}{l}\text { North America } \\
\quad(n=3243)\end{array}$ & $\begin{array}{c}\text { Western } \\
\text { Europe }(n=504)\end{array}$ & $P$ value \\
\hline \multicolumn{7}{|l|}{ Pre-randomization medical treatment } \\
\hline Total daily loop diuretic dose, $\mathrm{mg} *$ & $40(20,80)$ & $40(20,40)$ & $40(40,80)$ & $80(40,120)$ & $80(40,125)$ & $<0.001 \mathrm{NP}$ \\
\hline ACE Inhibitor/ARB & $911(51.7 \%)$ & $622(64.3 \%)$ & $462(69.5 \%)$ & $2039(62.9 \%)$ & $306(60.7 \%)$ & $<0.001$ \\
\hline Aldosterone antagonist & $453(25.7 \%)$ & $425(44.0 \%)$ & $228(34.3 \%)$ & $749(23.1 \%)$ & $137(27.2 \%)$ & $<0.001$ \\
\hline Hydralazine & $22(1.2 \%)$ & $4(0.4 \%)$ & $32(4.8 \%)$ & $472(14.6 \%)$ & $2(0.4 \%)$ & $<0.001$ \\
\hline Oral/Topical Nitrates & $513(29.1 \%)$ & $179(18.5 \%)$ & $82(12.3 \%)$ & $802(24.7 \%)$ & $105(20.8 \%)$ & $<0.001$ \\
\hline Anticoagulant & $113(6.4 \%)$ & $237(24.5 \%)$ & $98(14.7 \%)$ & $1084(33.4 \%)$ & $190(37.7 \%)$ & $<0.001$ \\
\hline Inotropes & $181(10.3 \%)$ & $27(2.8 \%)$ & $27(4.1 \%)$ & $56(1.7 \%)$ & $22(4.4 \%)$ & $<0.001$ \\
\hline Vasodilators & $395(22.4 \%)$ & $243(25.1 \%)$ & $179(26.9 \%)$ & $147(4.5 \%)$ & $95(18.8 \%)$ & $<0.001$ \\
\hline \multicolumn{7}{|l|}{ Device therapy } \\
\hline ACE Inhibitor/ARB & $1188(67.5 \%)$ & $742(76.7 \%)$ & $471(70.8 \%)$ & $1949 / 3242(60.1 \%)$ & $350(69.4 \%)$ & $<0.001$ \\
\hline Aldosterone antagonists & $792(45.0 \%)$ & $644(66.6 \%)$ & $380(57.1 \%)$ & $929 / 3243(28.6 \%)$ & $205(40.7 \%)$ & $<0.001$ \\
\hline Beta blockers & $909(51.6 \%)$ & $705(72.9 \%)$ & $378(56.8 \%)$ & $2258 / 3242(69.6 \%)$ & $329(65.3 \%)$ & $<0.001$ \\
\hline Digoxin & $787(44.7 \%)$ & $347(35.9 \%)$ & $210(31.6 \%)$ & $744 / 3242(22.9 \%)$ & $97(19.2 \%)$ & $<0.001$ \\
\hline Hydralazine & $35(2.0 \%)$ & $4(0.4 \%)$ & $33(5.0 \%)$ & $473 / 3243(14.6 \%)$ & $1(0.2 \%)$ & $<0.001$ \\
\hline Anticoagulant & $168(9.5 \%)$ & $331(34.2 \%)$ & $128(19.2 \%)$ & $993 / 3243(30.6 \%)$ & $211(41.9 \%)$ & $<0.001$ \\
\hline Oral/Topical Nitrates & $544(30.9 \%)$ & $132(13.7 \%)$ & $66(9.9 \%)$ & $714 / 3243(22.0 \%)$ & $80(15.9 \%)$ & $<0.001$ \\
\hline
\end{tabular}

All data are shown as n (\%) or median (Q1, Q3) unless otherwise specified.

$\mathrm{ACE}=$ angiotensin-converting enzyme; $\mathrm{ARBs}=$ angiotensin receptor blockers; $\mathrm{CRT}=$ cardiac resynchronization therapy; ICD $=$ implantable cardioverter-defibrillator; $\mathrm{NP}=$ nonparametric.

* Expressed as furosemide equivalents, calculated as $1 \mathrm{mg}$ torsemide $=2 \mathrm{mg}$ furosemide; $1 \mathrm{mg}$ bumetanide $=40 \mathrm{mg}$ furosemide.

with acute decompensated HF (ADHF). ${ }^{11}$ It was a global, clinical trial, which included patients from each of the 5 major geographical regions of the world. Importantly, it was the first large-scale acute HF trial to enroll patients from the AP region. Compared with previous analyses of geographical differences in HF trials, ${ }^{8,12-15}$ the fairly large sample sizes from each of the world regions allowed a robust analysis of the impact of geographical area on the clinical characteristics and outcomes of patients with acute HF.

\section{Methods}

The design and results of the ASCEND-HF trial have been reported previously. ${ }^{11,16}$ Briefly, the trial was an international, double-blind, placebo-controlled study evaluating the effectiveness and safety of nesiritide in addition to standard care versus standard care alone in 7,141 patients with ADHF. The trial was conducted from May 2007 to August 2010 at 398 centers in 30 countries throughout the world. Detailed inclusion and exclusion criteria have been described elsewhere. ${ }^{16}$ The 2 primary end points were a composite end point of all-cause mortality or HF readmission up to 30 days after randomization and the change in early dyspnea relief after study drug initiation.

Data on patient characteristics were collected during the baseline hospitalization. Rehospitalization and fatal events within 30 days after randomization were reviewed and categorized by an independent, blinded Clinical Events Committee. HF hospitalization was classified as previously described. ${ }^{11}$ In brief, HF hospitalization required typical clinical manifestations of worsening HF and the addition of or increase in treatment specifically for worsening HF. Allcause mortality was assessed through 180 days.

Enrollment took place in 30 countries in NA, LA, Europe, Asia, and Australia. For this analysis, countries were assigned to 1 of 5 geographical regions based on previous work ${ }^{8,15,17}$ : NA included the USA and Canada; LA included Argentina, Chile, Colombia, Brazil, and Mexico; WE included France, Germany, Greece, the Netherlands, Italy, Israel, Norway, Sweden, and the United Kingdom; CE included Bulgaria, Czech Republic, Lithuania, Poland, Romania, and Ukraine; and AP included Australia, India, China, Malaysia, New Zealand, Korea, Singapore, Taiwan, and Thailand.

Patients from different geographical areas were compared with respect to demographic, clinical, and laboratory data and clinical outcomes. All data are shown as median (interquartile range) or $\mathrm{n}(\%)$ unless otherwise specified. Outcomes of interest included length of the initial hospital stay (LOS), and the 30-day postrandomization outcome of all-cause mortality or HF hospitalization, and all-cause mortality. In addition, we assessed 180-day mortality by world region. For mortality and rehospitalization 
Table 3

Medication and device use at discharge in the subgroup of patients with LVEF $\leq 40 \% *$

\begin{tabular}{|c|c|c|c|c|c|c|}
\hline & $\begin{array}{c}\text { Asia / Pacific } \\
\quad(n=1416)\end{array}$ & $\begin{array}{l}\text { Central Europe } \\
\qquad(\mathrm{n}=581)\end{array}$ & $\begin{array}{l}\text { Latin America } \\
\qquad(\mathrm{n}=324)\end{array}$ & $\begin{array}{l}\text { North America } \\
\quad(n=1838)\end{array}$ & $\begin{array}{c}\text { Western } \\
\text { Europe }(n=181)\end{array}$ & $\mathrm{P}$ value \\
\hline Loop Diuretics & $1200 / 1401(85.7 \%)$ & $503 / 562(89.5 \%)$ & $283 / 323(87.6 \%)$ & $1665 / 1821(91.4 \%)$ & $169 / 180(93.9 \%)$ & $<0.001$ \\
\hline Total daily loop diuretic dose, mg & $40(40,80)$ & $40(40,120)$ & $40(40,80)$ & $80(40,160)$ & $60(8,125)$ & $<0.001 \mathrm{NP}$ \\
\hline ACE Inhibitor/ARB & $68.5 \%$ & $74.9 \%$ & $71.3 \%$ & $1150 / 1837(62.6 \%)$ & $75.1 \%$ & $<0.001$ \\
\hline Aldosterone antagonist $^{\dagger}$ & $624 / 1320(47.3 \%)$ & $335 / 466(71.9 \%)$ & $168 / 265(63.4 \%)$ & $601 / 1799(33.4 \%)$ & $97 / 172(56.4 \%)$ & $<0.001$ \\
\hline Beta blocker & $52.3 \%$ & $73.1 \%$ & $52.2 \%$ & $1333 / 1837(72.6 \%)$ & $72.4 \%$ & $<0.001$ \\
\hline Digoxin & $47.7 \%$ & $34.6 \%$ & $39.8 \%$ & $508 / 1837(27.7 \%)$ & $24.9 \%$ & $<0.001$ \\
\hline Hydralazine & $1.8 \%$ & $0.3 \%$ & $6.2 \%$ & $16.5 \%$ & 0 & $<0.001$ \\
\hline Anticoagulant & $8.2 \%$ & $34.9 \%$ & $18.8 \%$ & $31.7 \%$ & $40.3 \%$ & $<0.001$ \\
\hline Oral/Topical Nitrates & $32.6 \%$ & $12.9 \%$ & $12.3 \%$ & $23.2 \%$ & $14.9 \%$ & $<0.001$ \\
\hline Implantable cardioverter Defibrillator & $6 / 1321(0.5 \%)$ & $24 / 466(5.2 \%)$ & $4 / 265(1.5 \%)$ & $413 / 1799(23.0 \%)$ & $18 / 172(10.5 \%)$ & $<0.001$ \\
\hline
\end{tabular}

* Denominator as per the column heading unless otherwise noted.

${ }^{\dagger}$ LVEF cutoff $\leq 35 \%$ for aldosterone antagonists and ICD.

Table 4

Patient outcomes by region

\begin{tabular}{|c|c|c|c|c|c|c|}
\hline & $\begin{array}{l}\text { Asia / Pacific } \\
\quad(n=1762)\end{array}$ & $\begin{array}{l}\text { Central Europe } \\
\qquad(n=967)\end{array}$ & $\begin{array}{l}\text { Latin America } \\
\qquad(n=665)\end{array}$ & $\begin{array}{l}\text { North America } \\
\quad(n=3243)\end{array}$ & $\begin{array}{l}\text { Western } \\
\text { Europe } \\
(n=504)\end{array}$ & $\mathrm{P}$ value \\
\hline Length of hospitalization, days & $5.0(4.0,9.0)$ & $10.0(8.0,15.0)$ & $6.0(4.0,8.0)$ & $5.0(4.0,8.0)$ & $\begin{array}{l}8.0 \\
(5.0,11.0)\end{array}$ & $<0.001 \mathrm{NP}$ \\
\hline $\begin{array}{l}\text { Mortality or HF rehospitalization } \\
\text { at 30-days }\end{array}$ & $125(7.5 \%)$ & $49(5.1 \%)$ & $71(11.0 \%)$ & $404(12.7 \%)$ & $37(7.7 \%)$ & $<0.001$ \\
\hline Mortality at 30 -days & $66(3.8 \%)$ & $30(3.1 \%)$ & $43(6.5 \%)$ & $111(3.4 \%)$ & $23(4.6 \%)$ & 0.003 \\
\hline Mortality at 180 -days & $200(11.6 \%)$ & $88(9.3 \%)$ & $112(17.3 \%)$ & $426(13.3 \%)$ & $74(15.1 \%)$ & $<0.001$ \\
\hline
\end{tabular}

Data are shown as median (interquartile range) or $\mathrm{n}(\%)$.

events, odds ratios (30-day events) or hazard ratios (180-day mortality) and $95 \%$ CIs of the patients from different geographical areas, compared with those in NA, were calculated using Cox regression analysis with and without adjustment for baseline covariates. Adjustment covariates included clinically relevant variables that have been used in previous ASCEND-HF models. ${ }^{18,19}$ Kaplan-Meier plots were generated by region for clinical outcomes. A p value $<0.05$ was used to indicate statistical significance. There was no adjustment for multiple comparisons given the exploratory nature of this analysis. All statistical analyses were performed at Duke Clinical Research Institute (Durham, North Carolina) using SAS version 9.22 (SAS Institute, Cary, North Carolina).

\section{Results}

Of the 7,141 patients enrolled, 3,243 patients were from 214 centers in NA (15.15 patients per site), 665 patients were from 39 sites in LA (17.05 patients per site), 506 patients were from 35 sites in WE (14.4 patients per site), 967 patients were from 48 sites in CE (20.15 patients per site), 1,762 patients were from 62 sites in the AP region (28.42 patients per site). Supplementary Table 1 presents the enrollment numbers by country. Baseline characteristics of the patients subdivided on the basis of the 5 geographical regions are presented in Table 1 .
Patients from AP were younger than in other world regions. Nearly, all subjects from Europe versus $64 \%$ of those from NA were white. Black and Hispanic patients were $32.1 \%$ and $6.5 \%$, respectively, of the subjects from NA, Asian patients constituted $97.2 \%$ of the subjects from AP, and Hispanic patients constituted $97.3 \%$ of those from LA.

The proportion of subjects with a history of coronary artery disease (CAD) was higher in the patients from $\mathrm{CE}$, NA, and WE versus subjects from AP and LA. Previous percutaneous coronary intervention was most common in NA and WE, whereas other regions such as CE had less previous percutaneous coronary intervention despite the high prevalence of CAD and previous myocardial infarction. A history of hypertension was also more common in the subjects from NA, LA, CE, and WE compared with those from AP. The proportions of patients with atrial fibrillation were highest in $\mathrm{CE}(57 \%)$ and lowest in AP $(17 \%)$. Other co-morbidities, such as chronic respiratory disease and cerebrovascular disease were also more frequent in patients from NA, WE, and CE than in LA and AP. An exception was the prevalence of diabetes, which was similarly high in $\mathrm{AP}(42 \%)$ as compared with other regions (29\% to $49 \%$ ).

Systolic blood pressure at baseline was higher in the patients from $\mathrm{CE}$ (median $130 \mathrm{~mm} \mathrm{Hg}$ ) versus patients in NA and WE (124 mm Hg in both regions) and patients from LA and AP (median $120 \mathrm{~mm} \mathrm{Hg}$ ). Heart rate was higher in patients from $\mathrm{AP}$ and $\mathrm{CE}$ compared with other regions. 
Table 5

Adjusted* regional outcomes compared with North America

\begin{tabular}{lccc}
\hline Region & $\begin{array}{c}\text { Death / HF } \\
\text { rehospitalization } \\
\text { at day 30 } \\
\text { OR }(95 \% \mathrm{CI})\end{array}$ & $\begin{array}{c}\text { Death at day 30 } \\
\text { OR }(95 \% \mathrm{CI})\end{array}$ & $\begin{array}{c}\text { Death at 180-days } \\
\text { HR }(95 \% \mathrm{CI})\end{array}$ \\
\hline Asia-Pacific & $0.62(0.48,0.79)$ & $0.93(0.67,1.31)$ & $0.77(0.63,0.94)$ \\
Central Europe & $0.46(0.33,0.64)$ & $0.87(0.57,1.32)$ & $0.67(0.52,0.86)$ \\
Latin America & $0.77(0.57,1.04)$ & $1.10(0.75,1.62)$ & $0.85(0.66,1.08)$ \\
Western Europe & $0.52(0.35,0.75)$ & $0.82(0.51,1.32)$ & $0.77(0.58,1.01)$ \\
Overall P-value & $<0.0001$ & 0.66 & 0.0011 \\
\hline
\end{tabular}

* Adjustment variables as follows: mortality 30 days and 1 to 180 days: age, baseline BUN (log), sodium, systolic blood pressure dichotomized at $140 \mathrm{~mm} \mathrm{Hg}$, and dyspnea (at rest vs moderate exercise); death/HF hospitalization 30 days: age (dichotomized at 55yo), baseline BUN (log), cerebrovascular disease, creatinine (log), depression, dyspnea (at rest vs moderate exercise), HF hospitalization in last year, qualifying episode jugular venous distension (yes/no), sodium (continuous and truncated at 140), systolic blood pressure dichotomized 140, and baseline chronic respiratory disease.

Despite fairly similar median creatinine values across world regions, patients from LA and WE had higher values of serum blood urea nitrogen. Serum $\mathrm{N}$-terminal pro brain natriuretic peptide (NT-proBNP) plasma levels were slightly higher in the patients from LA, NA, and AP compared with the patients from Europe. QRS duration was longer in patients from WE and NA compared with other regions. Median left ventricular ejection fraction (LVEF) was slightly lower in NA and AP.

Medication and device use data are presented in Table 2 (all patients) and Table 3 (patients with known reduced LVEF). Table 4 and Figure 1 present outcomes data by region. After risk adjustment (Table 5), death through 30 days did not significantly differ across world regions, whereas 30-day mortality or HF hospitalization and 180-day deaths were comparatively greater in NA. Lost-to-follow-up (LTFU) numbers at 30 days also varied by world region with the lowest LTFU in NA at $39(1.2 \%)$ and higher LTFU numbers in other world regions: $36(1.7 \%)$ in CE, $36(2.0 \%)$ in AP, $14(2.1 \%)$ in LA, and $12(2.4 \%)$ in WE.

\section{Discussion}

Our study shows major differences in the clinical characteristics, medications, 30-day rehospitalization rates, and 180-day mortality between patients with ADHF enrolled from different geographical areas. Compared with previous studies of regional differences, ${ }^{8,12-14}$ this was the first global ADHF trial including patients from the AP region and, differently from recent trials, ${ }^{15}$ patients from NA are largely represented.

Globalization of randomized clinical trials for the assessment of new therapies is a hallmark of current research. ${ }^{1-3}$ It is therefore critical to assess potential differences in the characteristics, treatment, and outcomes between the patients from different geographical areas. This issue has been assessed both in retrospective analyses of HF randomized controlled trials ${ }^{9}$ and in registries of patients with $\mathrm{HF}^{20-23}$ and may,,${ }^{9,24}$ or may not, ${ }^{14}$ have an influence on the effects of drug treatment. For instance, in the primary publication of the ASCEND trial, ${ }^{11}$ enrolling location was the only subgroup analysis that demonstrated a differential association with the primary end point of all-cause death or $\mathrm{HF}$ rehospitalization through 30 days as LA location favored nesiritide over placebo. Importantly, despite being prespecified, these data should be viewed as hypothesisgenerating given the large number of subgroups tested and the potential for statistical chance.

Efficacy of Vasopressin Antagonism in Heart Failure Outcome Study With Tolvaptan (EVEREST) was the first trial in ADHF with a large number of patients enrolled from Eastern Europe. ${ }^{12}$ It showed meaningful differences with the patients from Eastern Europe having the highest values of systolic blood pressure and LVEF and the lowest values of serum blood urea nitrogen and NT-proBNP plasma levels and, accordingly, the best outcomes. ${ }^{12}$ Similar data were found in the present analysis of the ASCEND-HF trial although with less marked differences. In the recent Placebo-Controlled Randomized Study of the Selective $A_{1}$ Adenosine Receptor Antagonist Rolofylline for Patients Hospitalized with Acute Decompensated Heart Failure and Volume Overload to Assess Treatment Effect on Congestion and Renal Function (PROTECT) analysis, lower short-term rehospitalization and similar mortality was also seen in Eastern Europe as compared with WE. ${ }^{8}$ Thus, data support a consistent finding of marked regional differences in short-term clinical outcomes that are driven by rehospitalization.

Unlike previous studies, ASCEND-HF was the first ADHF trial in which patients from the AP area were included, with $97.2 \%$ of these patients of Asian ethnicity. Distinct characteristics were found in this geographical area. Patients from AP were younger, were less likely to have hypertension, CAD, and other co-morbidities, except for diabetes, and were less likely to receive angiotensinconverting enzyme inhibitors/angiotensin receptor blockers and $\beta$ blockers. These findings confirm previous surveys from this area. ${ }^{25}$ Despite these differences, and differently from what was suggested by other studies, ${ }^{15,26}$ outcomes of the patients from AP were similar to other areas. It is possible that the favorable effects of lower age and less co-morbidities were counterbalanced by the untoward effects of the lower use of HF therapies. These findings are distinct from the Aliskiren Trial on Acute Heart Failure Outcomes (ASTRONAUT) study which showed the highest risk for mortality in the AP region. Importantly, the AP population in ASTRONAUT was different from ASCEND with significantly more ischemic origin $(78 \%$ vs $48 \%$ in ASCEND) and restriction to HF with reduced LVEF in ASTRONAUT.

The present analysis extends the findings of an earlier assessment of global variation in quality of care in ASCEND-HF. ${ }^{27}$ The previous analysis focused on regional differences in discharge quality indicators such as medication and device use as well as blood pressure control. In terms of meeting performance opportunities, there were regional differences observed with $\mathrm{CE}$ highest at $64 \%$ conformity with quality of care targets, followed by NA (63\%), WE (61\%), LA (56\%), and $\mathrm{AP}(51 \%$; p <0.0001). This previous analysis did not explore potential implications on clinical outcomes as in the present analysis. 

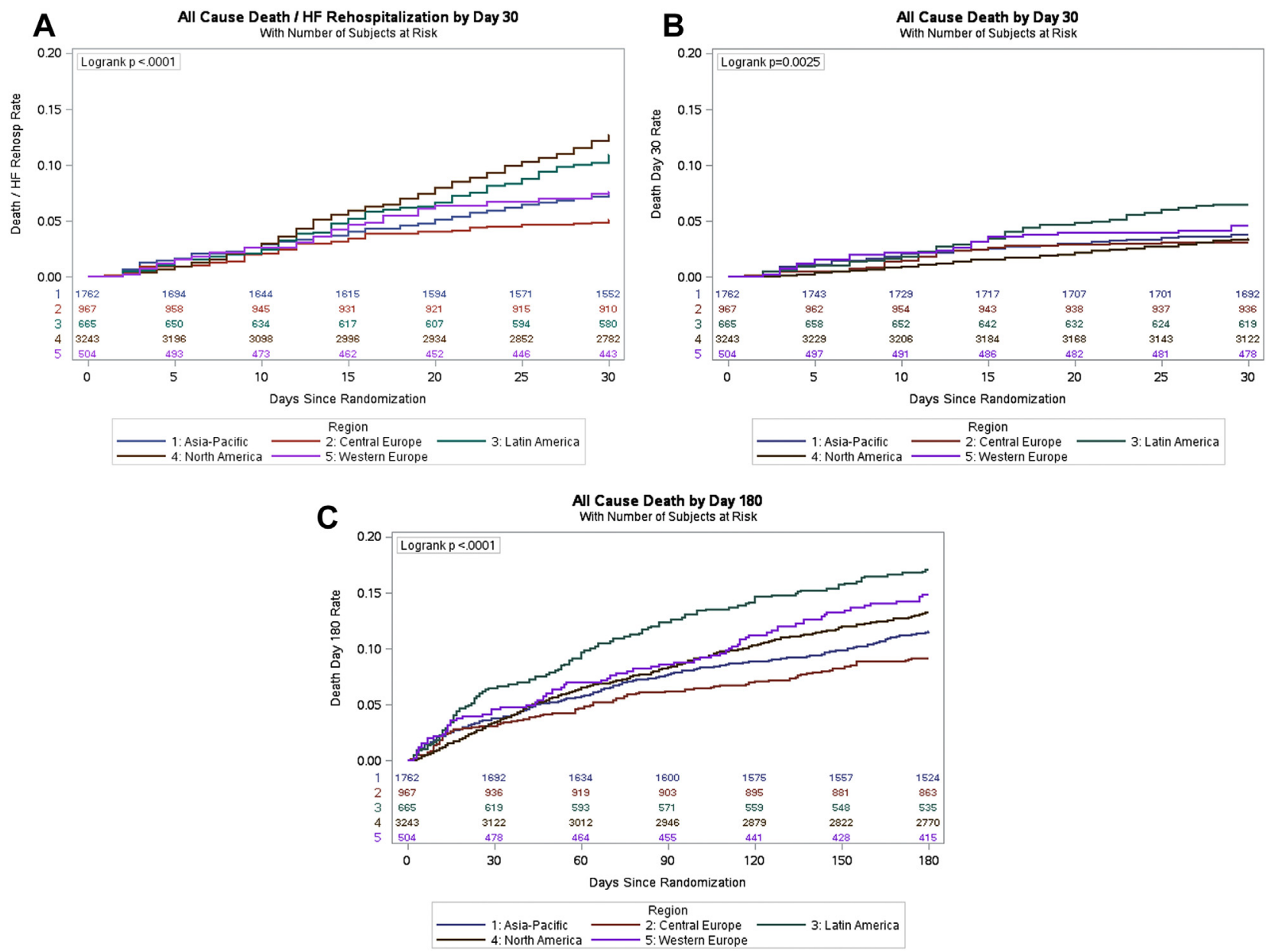

Figure 1. (A) All-cause mortality or HF hospitalization through 30-day by geographical region. (B) All-cause mortality through 30-day by geographical region. (C) All-cause mortality through 180 -day by geographical region. Rehosp $=$ rehospitalization.

The present study shows an important geographic difference between LOS, rehospitalizations, and mortality as outcome measurements in ADHF trials. Although LOS and rehospitalization rates were highly dependent on geographical differences, short-term mortality rates after risk adjustment were not. Early postdischarge rehospitalization rates are influenced by many variables, such as co-morbidities and social factors, not necessarily related with the severity of HF. The poor correlation between 30-day rehospitalization rates and 30-day mortality rates has been shown in previous analyses. ${ }^{28,29}$ In addition, a previous analysis from ASCEND demonstrated that LOS was independently associated with the risk of rehospitalization but not 30-day mortality. ${ }^{30}$ This previous analysis focused on country level comparisons rather than by world region and did not explore long-term outcomes. Moreover, another previous ASCEND analysis comparing outcomes in the US and Canada demonstrated lower odds of 30-day mortality in Canada after risk adjustment. ${ }^{18}$ Thus, differences in clinical outcomes may exist between countries within the same region. In sum, these observations may have implications for end points selection in major, multicenter, global clinical trials as mortality alone, differently from LOS and rehospitalization rates, may be less dependent on geographical areas.
The specific reasons for increased 180-day mortality in NA and comparatively lower mortality in CE are not entirely clear but is consistent with previous data. ${ }^{12}$ These observations may be due in part to the increased co-morbidity burden in NA as well as additional markers of increased disease severity such as lower blood pressure and EF as well as higher NT-proBNP level and wider QRS. Moreover, the usage of angiotensin-converting enzyme inhibitors and aldosterone antagonists was lower in NA compared with other regions despite lower EF likely related to lower blood pressure and worse renal function as well as differential prescribing patterns in the context of shorter LOS as seen previously. ${ }^{8}$ These risk factors may have led to increased mortality in NA despite protective effects related to higher usage of implantable cardioverter defibrillators (ICDs). We adjusted the clinical outcomes based on previously established covariate lists that have been consistently used in the ASCEND data set. However, both recognized and unrecognized factors, which were not adjusted for may have influenced these results, and we cannot rule out residual confounding. For instance, there may have also been underreporting of mortality in some regions given differential LTFU across enrolling regions.

Future trials could consider specifying requirements for background guideline-directed medical therapy before trial 
enrollment. Although these recommendations would provide support for the argument that a novel therapy provides incremental benefit beyond current standard of care, this approach also has limitations. For instance, prescriptive trial entry criteria for specific medications are a challenge when costs for these background therapies are not covered as part of trial involvement. These considerations are particularly relevant in geographical regions without universal health care systems and with variable medication coverage. Moreover, questions of generalizability of study results can arise when background therapies in the setting of a trial are distinct from usual care.

The present findings also highlight the importance of recognizing these regional differences when selecting sites for a future trial. For earlier phase investigation, it may be necessary to select sites from specific world regions to enroll patients with the underlying substrate considered as the most sensitive to the effects of the novel therapy. For instance, certain myocardial-targeting drugs could work more favorably in those patients with larger areas of viable myocardium. Moreover, the regional differences should also be recognized when selecting trial end points and determining appropriate enrolling regions. Differential use of ICDs influences mode of death and the prevalence of co-morbidities influences the proportion of noncardiovascular clinical events which both may affect a study's statistical power. Future studies could consider either stratification by region or inclusion of region as an adjustment factor for outcomes involving rehospitalization or hospital LOS. Although shortterm mortality rates across regions were similar after adjustment, regional differences in long-term event rates suggest that it might be wise when designing clinical trials to consider these differences when calculating sample size or determining the distribution of subjects between regions.

This was a retrospective analysis from a clinical trial with specific entry criteria such that generalizability is uncertain. However, ASCEND represents that largest ADHF data set to date and has larger representation of each of the world regions compared with many earlier analyses. We defined the different geographical regions based on previous studies, but regional differences exist even within these groupings.

\section{Disclosures}

Dr. Metra has received consulting honoraria from Bayer, Novartis, Servier. Dr. Mentz receives research support with the grant U10HL110312 from National Institutes of Health, Amgen, Gilead, Novartis, Otsuka, and ResMed; and honoraria from HeartWare, Luitpold, Novartis, ResMed, and Thoratec. Dr. Costanzo has received consulting honoraria from Metronic, St. Jude, Respicardia, and ZS Pharma; and grants to Advocate Heart Institute from Respicardia, Cardikinetix, Impulse Dynamics, St. Jude, Novartis, Lung LLC, and ARCA. Dr. Fonarow reports consulting for Abbot, Amgen, Bayer, Baxter, Janssen, Novartis, Medtronic. The other authors have no conflicts of interest to disclose.

\section{Supplementary Data}

Supplementary data associated with this article can be found, in the online version, at http://dx.doi.org/10.1016/ j.amjcard.2016.03.002.
1. Glickman SW, McHutchison JG, Peterson ED, Cairns CB, Harrington RA, Califf RM, Schulman KA. Ethical and scientific implications of the globalization of clinical research. $N$ Engl J Med 2009;360: 816-823.

2. Massie BM. Globalization of clinical trials how should we interpret differences in outcomes? J Am Coll Cardiol 2011;58:923-924.

3. Pocock S, Calvo G, Marrugat J, Prasad K, Tavazzi L, Wallentin L, Zannad F, Alonso Garcia A. International differences in treatment effect: do they really exist and why? Eur Heart J 2013;34:1846-1852.

4. Gheorghiade M, Vaduganathan M, Greene SJ, Mentz RJ, Adams KF Jr, Anker SD, Arnold M, Baschiera F, Cleland JG, Cotter G, Fonarow GC, Giordano C, Metra M, Misselwitz F, Muhlhofer E, Nodari S, Frank Peacock W, Pieske BM, Sabbah HN, Sato N, Shah MR, Stockbridge NL, Teerlink JR, van Veldhuisen DJ, Zalewski A, Zannad F, Butler J. Site selection in global clinical trials in patients hospitalized for heart failure: perceived problems and potential solutions. Heart Fail Rev 2014; $19: 135-152$.

5. Wallentin L, Becker RC, Budaj A, Cannon CP, Emanuelsson H, Held C, Horrow J, Husted S, James S, Katus H, Mahaffey KW, Scirica BM, Skene A, Steg PG, Storey RF, Harrington RA, Investigators P, Freij A, Thorsen M. Ticagrelor versus clopidogrel in patients with acute coronary syndromes. $N$ Engl J Med 2009;361:1045-1057.

6. Mahaffey KW, Wojdyla DM, Carroll K, Becker RC, Storey RF, Angiolillo DJ, Held C, Cannon CP, James S, Pieper KS, Horrow J, Harrington RA, Wallentin L; PLATO Investigators. Ticagrelor compared with clopidogrel by geographic region in the Platelet Inhibition and Patient Outcomes (PLATO) trial. Circulation 2011;124: $544-554$.

7. Pitt B, Pfeffer MA, Assmann SF, Boineau R, Anand IS, Claggett B, Clausell N, Desai AS, Diaz R, Fleg JL, Gordeev I, Harty B, Heitner JF, Kenwood CT, Lewis EF, O'Meara E, Probstfield JL, Shaburishvili T, Shah SJ, Solomon SD, Sweitzer NK, Yang S, McKinlay SM; TOPCAT Investigators. Spironolactone for heart failure with preserved ejection fraction. N Engl J Med 2014;370:1383-1392.

8. Mentz RJ, Cotter G, Cleland JG, Stevens SR, Chiswell K, Davison BA, Teerlink JR, Metra M, Voors AA, Grinfeld L, Ruda M, Mareev V, Lotan C, Bloomfield DM, Fiuzat M, Givertz MM, Ponikowski P, Massie BM, O'Connor CM. International differences in clinical characteristics, management, and outcomes in acute heart failure patients: better short-term outcomes in patients enrolled in Eastern Europe and Russia in the PROTECT trial. Eur J Heart Fail 2014;16:614-624.

9. O’Connor CM, Fiuzat M, Swedberg K, Caron M, Koch B, Carson PE, Gattis-Stough W, Davis GW, Bristow MR. Influence of global region on outcomes in heart failure beta-blocker trials. J Am Coll Cardiol 2011;58:915-922.

10. Ferreira JP, Girerd N, Rossignol P, Zannad F. Geographic differences in heart failure trials. Eur J Heart Fail 2015;17:893-905.

11. O'Connor CM, Starling RC, Hernandez AF, Armstrong PW, Dickstein K, Hasselblad V, Heizer GM, Komajda M, Massie BM, McMurray JJ, Nieminen MS, Reist CJ, Rouleau JL, Swedberg K, Adams KF Jr, Anker SD, Atar D, Battler A, Botero R, Bohidar NR, Butler J, Clausell N, Corbalan R, Costanzo MR, Dahlstrom U, Deckelbaum LI, Diaz R, Dunlap ME, Ezekowitz JA, Feldman D, Felker GM, Fonarow GC, Gennevois D, Gottlieb SS, Hill JA, Hollander JE, Howlett JG, Hudson MP, Kociol RD, Krum H, Laucevicius A, Levy WC, Mendez GF, Metra M, Mittal S, Oh BH, Pereira NL, Ponikowski P, Tang WH, Tanomsup S, Teerlink JR, Triposkiadis F, Troughton RW, Voors AA, Whellan DJ, Zannad F, Califf RM. Effect of nesiritide in patients with acute decompensated heart failure. N Engl J Med 2011;365:32-43.

12. Blair JE, Zannad F, Konstam MA, Cook T, Traver B, Burnett JC Jr, Grinfeld L, Krasa H, Maggioni AP, Orlandi C, Swedberg K, Udelson JE, Zimmer C, Gheorghiade M; EVEREST Investigators. Continental differences in clinical characteristics, management, and outcomes in patients hospitalized with worsening heart failure results from the EVEREST (Efficacy of Vasopressin Antagonism in Heart Failure: Outcome Study with Tolvaptan) program. J Am Coll Cardiol 2008;52: 1640-1648.

13. Massie BM, Cleland JG, Armstrong PW, Horowitz JD, Packer M, Poole-Wilson PA, Ryden L. Regional differences in the characteristics and treatment of patients participating in an international heart failure trial. The Assessment of Treatment with Lisinopril and Survival (ATLAS) trial investigators. J Card Fail 1998;4:3-8.

14. Pitt B, Zannad F, Gheorghiade M, Martinez F, Love TE, Daniel C, Ahmed A. Transatlantic similarities and differences in major natural 
history endpoints of heart failure after acute myocardial infarction: a propensity-matched study of the EPHESUS trial. Int J Cardiol 2010;143:309-316.

15. Greene SJ, Fonarow GC, Solomon SD, Subacius H, Maggioni AP, Bohm M, Lewis EF, Zannad F, Gheorghiade M. Global variation in clinical profile, management, and post-discharge outcomes among patients hospitalized for worsening chronic heart failure: findings from the ASTRONAUT trial. Eur J Heart Fail 2015;17:591-600.

16. Hernandez AF, O’Connor CM, Starling RC, Reist CJ, Armstrong PW, Dickstein K, Lorenz TJ, Gibler WB, Hasselblad V, Komajda M, Massie B, McMurray JJ, Nieminen M, Rouleau JL, Swedberg K, Califf RM. Rationale and design of the Acute Study of Clinical Effectiveness of Nesiritide in Decompensated Heart Failure trial (ASCEND-HF). Am Heart J 2009;157:271-277.

17. Mentz RJ, Kaski JC, Dan GA, Goldstein S, Stockbridge N, AlonsoGarcia A, Ruilope LM, Martinez FA, Zannad F, Pitt B, Fiuzat M, O'Connor CM. Implications of geographical variation on clinical outcomes of cardiovascular trials. Am Heart J 2012;164:303-312.

18. Kaul P, Reed SD, Hernandez AF, Howlett JG, Ezekowitz JA, Li Y, Zheng Y, Rouleau JL, Starling RC, O'Connor CM, Califf RM, Armstrong PW. Differences in treatment, outcomes, and quality of life among patients with heart failure in Canada and the United States. JACC Heart Fail 2013;1:523-530.

19. Khazanie P, Heizer GM, Hasselblad V, Armstrong PW, Califf RM, Ezekowitz J, Dickstein K, Levy WC, McMurray JJV, Metra M, Wilson Tang WH, Teerlink JR, Voors AA, O'Connor CM, Hernandez AF, Starling R. Predictors of clinical outcomes in acute decompensated heart failure: acute study of clinical effectiveness of nesiritide in decompensated heart failure outcome models. Am Heart J 2015;170: 290-297.

20. van Veldhuisen DJ, Charlesworth A, Crijns HJ, Lie KI, Hampton JR. Differences in drug treatment of chronic heart failure between European countries. Eur Heart J 1999;20:666-672.

21. Collins SP, Pang PS, Lindsell CJ, Kyriacou DN, Storrow AB, Hollander JE, Kirk JD, Miller CD, Nowak R, Peacock WF, Tavares M, Mebazaa A, Gheorghiade M. International variations in the clinical, diagnostic, and treatment characteristics of emergency department patients with acute heart failure syndromes. Eur J Heart Fail 2010;12: $1253-1260$.

22. Sato N, Kajimoto K, Asai K, Mizuno M, Minami Y, Nagashima M, Murai K, Muanakata R, Yumino D, Meguro T, Kawana M, Nejima J, Satoh T, Mizuno K, Tanaka K, Kasanuki H, Takano T; ATTEND Investigators. Acute decompensated heart failure syndromes (ATTEND) registry. A prospective observational multicenter cohort study: rationale, design, and preliminary data. Am Heart J 2010;159: 949-955 e1.

23. Maggioni AP, Dahlstrom U, Filippatos G, Chioncel O, Leiro MC, Drozdz J, Fruhwald F, Gullestad L, Logeart D, Fabbri G, Urso R, Metra M, Parissis J, Persson H, Ponikowski P, Rauchhaus M, Voors AA, Nielsen OW, Zannad F, Tavazzi L; Heart Failure Association of the European Society of Cardiology (HFA). EURObservational Research Programme: regional differences and 1-year follow-up results of the Heart Failure Pilot Survey (ESC-HF pilot). Eur J Heart Fail 2013;15:808-817.

24. Pfeffer MA, Claggett B, Assmann SF, Boineau R, Anand IS, Clausell N, Desai AS, Diaz R, Fleg JL, Gordeev I, Heitner JF, Lewis EF, O'Meara E, Rouleau JL, Probstfield JL, Shaburishvili T, Shah SJ, Solomon SD, Sweitzer NK, McKinlay SM, Pitt B. Regional variation in patients and outcomes in the Treatment of Preserved Cardiac Function Heart Failure With an Aldosterone Antagonist (TOPCAT) trial. Circulation 2015;131:34-42.

25. Shimokawa H, Miura M, Nochioka K, Sakata Y. Heart failure as a general pandemic in Asia. Eur J Heart Fail 2015;17:884-892.

26. Shantsila E, Lip GY, Gill PS. Systolic heart failure in South Asians. Int $J$ Clin Pract 2011;65:1274-1282.

27. Howlett JG, Ezekowitz JA, Podder M, Hernandez AF, Diaz R, Dickstein K, Dunlap ME, Corbalan R, Armstrong PW, Starling RC, O'Connor CM, Califf RM, Fonarow GC. Global variation in quality of care among patients hospitalized with acute heart failure in an international trial: findings from the acute study clinical effectiveness of nesiritide in decompensated heart failure trial (ASCEND-HF). Circ Cardiovasc Qual Outcomes 2013;6:534-542.

28. Krumholz HM, Lin Z, Keenan PS, Chen J, Ross JS, Drye EE, Bernheim SM, Wang Y, Bradley EH, Han LF, Normand SL. Relationship between hospital readmission and mortality rates for patients hospitalized with acute myocardial infarction, heart failure, or pneumonia. JAMA 2013;309:587-593.

29. Kociol RD, Liang L, Hernandez AF, Curtis LH, Heidenreich PA, Yancy $\mathrm{CW}$, Fonarow GC, Peterson ED. Are we targeting the right metric for heart failure? Comparison of hospital 30-day readmission rates and total episode of care inpatient days. Am Heart J 2013;165: 987-994.e1.

30. Eapen ZJ, Reed SD, Li Y, Kociol RD, Armstrong PW, Starling RC, McMurray JJ, Massie BM, Swedberg K, Ezekowitz JA, Fonarow GC, Teerlink JR, Metra M, Whellan DJ, O'Connor CM, Califf RM, Hernandez AF. Do countries or hospitals with longer hospital stays for acute heart failure have lower readmission rates?: Findings from ASCEND-HF. Circ Heart Fail 2013;6:727-732. 